$\mathrm{DE}$

M E D I C I N A

T R O P I C A L

$\mathrm{DE}$

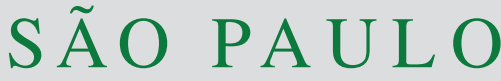

JOURNAL OF THE SÃO PAULO INSTITUTE OF TROPICAL MEDICINE

'Universidade Federal do Paraná, Programa de Pós-Graduação em Ciências Veterinárias, Curitiba, Paraná, Brazil

'Universidade Federal do Espírito Santo, Centro de Ciências da Saúde, Programa de Pós-Graduação em Doenças Infecciosas, Vitória, Espírito Santo, Brazil

${ }^{3}$ Asociación Colombiana de Infectología, Comité de Medicina Tropical, Zoonosis y Medicina del Viajero, Bogotá, Colombia

${ }^{4}$ Centro Social Nossa Senhora do Bom Parto, Núcleo de Convivência São Martinho de Lima, São Paulo, São Paulo, Brazil

${ }^{5}$ Universidade de São Paulo, São Paulo, São Paulo, Brazil

${ }^{6}$ Universidade Federal do Paraná, Departamento de Medicina Veterinária, Curitiba, Paraná, Brazil

Correspondence to: Álvaro A. FacciniMartínez

Universidade Federal do Espírito Santo, Centro de Ciências da Saúde, Programa de Pós-Graduação em Doenças Infecciosas, Av. Marechal Campos, 1468, CEP 29.040090, Maruípe, Vitória, ES, Brazil

Tel: +55 27 99830-1815

E-mail: afaccini@gmail.com

Received: 4 January 2018

Accepted: 8 January 2018

\section{Preliminary report of body lice infesting homeless people in Brazil}

\section{Dear Editor}

The Pediculus humanus humanus (body louse or Brazilian "muquirana") has been causing infestations in vulnerable human populations with poor hygiene habits such as homeless, inmates and refugees ${ }^{1} . P$. $h$. humanus is the only of three lice species related to potentially lethal infectious diseases, recognized as a competent vector of Rickettsia prowazekii, Bartonella quintana and Borrelia recurrentis ${ }^{2}$. Recent data from Marseille, France (4317'47"N 5²2'12"E) and Bogotá, Colombia $\left(4^{\circ} 42^{\prime} 40^{\prime \prime} \mathrm{N} 74^{\circ} 4^{\prime} 20^{\prime \prime} \mathrm{W}\right)$ have described a decrease over time in overall body lice prevalence and have identified independent risk factors (older age, length of stay in France for migrants, frequent consumption of alcohol and tobacco smoking) for infestation among French homeless people ${ }^{3}$, alongside with $11.7 \%$ body lice prevalence in Colombian homeless ${ }^{4}$. Despite a Mediterranean climate in Marseille $\left(14.5^{\circ} \mathrm{C}\right)$ and a subtropical highland climate in Bogotá $\left(12^{\circ} \mathrm{C}\right)$, both cities provide similar mild average temperatures that favor body lice interaction with homeless people.

Based on these concomitant findings, we have first investigated body lice in a homeless of Curitiba $\left(25^{\circ} 25^{\prime} 47^{\prime \prime} \mathrm{S}, 49^{\circ} 16^{\prime} 19^{\prime \prime} \mathrm{W}\right)$, the coldest and the eighth biggest Brazilian State capital (average temperature $16.5^{\circ} \mathrm{C}$ ), with a similar subtropical highland climate in comparison with Bogotá. A homeless volunteer found in downtown square, presenting truncal pruritic and scratching lesions was examined. Lice were collected using forceps and identified as Pediculus humanus humanus (body lice) based on the recovery site (clothing). Due to this positive finding, similar survey was performed in a homeless shelter of downtown São Paulo (2333'1"S, $\left.46^{\circ} 38^{\prime} 2^{\prime \prime} \mathrm{W}\right)$, the largest South American city, with humid subtropical climate and average temperatures varying from $19{ }^{\circ} \mathrm{C}$ (winter) to $25^{\circ} \mathrm{C}$ (summer).

Overall, several nits were evidenced in clothing seams with 10 (7 nymphs and 3 adults) body lice recovered in the Curitiba's homeless and 57 (50 nymphs and 7 adults) in clothing from 2 out of 5 homeless examined in São Paulo (Figure 1).

Limited body lice records were described in Brazil,

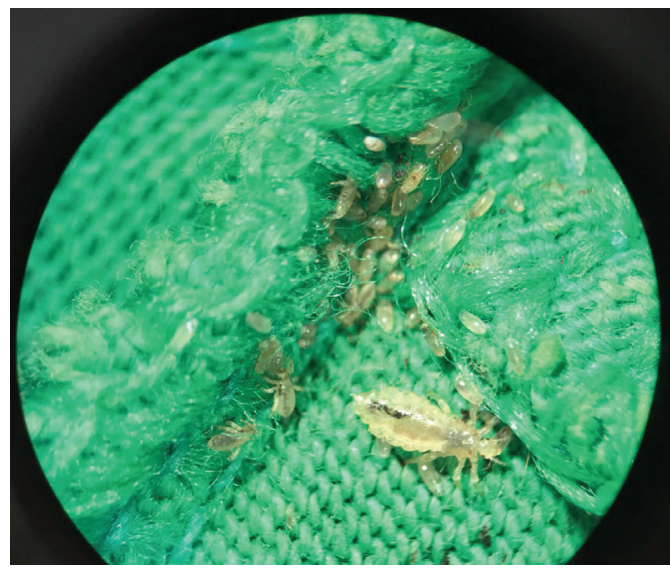
infesting clothes and bedding of three relatives living in precarious household conditions in a shantytown in São Paulo ${ }^{5}$, and a considerable infestation in a homeless person with abrasions and hyperchromic skin lesions ${ }^{6}$. Nevertheless, in this last report P.h. capitis may have been mistaken for $P$. h. humanus as specimens were collected in hairy body areas and not in clothes ${ }^{5}$.

Our preliminary findings confirmed the suspicious body lice circulation among homeless populations in major Brazilian cities, drawing attention to the diagnosis, control and prevention of body lice infestation in vulnerable populations of other 
tropical cities in Latin America, and suggesting that further investigation of potential associated diseases should be performed.

\section{Mara Lucia Gravinatti ${ }^{1}$ Álvaro A. Faccini-Martínez ${ }^{2,3}$ Sandro Ricardo Ruys ${ }^{4}$ Jorge Timenetsky ${ }^{5}$ Alexander Welker Biondo ${ }^{6}$}

\section{REFERENCES}

1. Brouqui P, Raoul D. Arthropod-borne diseases in homeless. Ann N Y Acad Sci. 2006;1078:223-35.

2. Badiaga S, Raoult D, Brouqui P. Preventing and controlling emerging and reemerging transmissible diseases in the homeless. Emerg Infect Dis. 2008;14:1353-9.
3. Ly TD, Touré Y, Calloix C, Badiaga S, Raoult D, Tissot-Dupont $\mathrm{H}$, et al. Changing demographics and prevalence of body lice among homeless persons, Marseille, France. Emerg Infect Dis. 2017;23:1894-7.

4. Faccini-Martínez ÁA, Márquez AC, Bravo-Estupiñan DM, Calixto OJ, López-Castillo CA, Botero-García CA, et al. Bartonella quintana and typhus group rickettsiae exposure among homeless persons, Bogotá, Colombia. Emerg Infect Dis. 2017;23:1876-9.

5. Linardi PM, Soares Barata JM, Urbinatti PR, Souza D, Botelho JR, De Maria M. Infestação por Pediculus humanus (Anoplura: Pediculidae) no Município de São Paulo, SP, Brasil. Rev Saude Publica. 1998;32:77-81.

6. Martins LG, Bernardes Filho F, Quaresma MV, Bellott TR, Botelho LN, Prata AC. Dermoscopy applied to pediculosis corporis diagnosis. An Bras Dermatol. 2014;89:513-4. 